\title{
Alteration of Enzyme Activity in Rat Liver following the Acute and Chronic Administration of Nicotine ${ }^{1}$
}

\author{
R. W. Ruddon AND A. M. COHEN ${ }^{2}$ \\ Department of Pharmacology, \\ The University of Michigan Medical School, \\ Ann Arbor, Michigan 48104
}

Received May 26, 1969

\begin{abstract}
Alteration of Enzyme Activity in Rat Liver Following the Acute and Chronic Administration of Nicotine. Ruvuon, R. W., and CoHen, A. M. (1970). Toxicol. Appl. Pharmacol. 16, 613-625. The ip injection of nicotine ( 2 or $4 \mathrm{mg} / \mathrm{kg}$ ) to rats produced an increase in tryptophan pyrrolase activity in liver within 2 hours after drug administration. The elevation in enzyme activity reached a peak at 4 hours after drug injection and returned toward control levels by 6 hours. Administration of $4 \mathrm{mg}$ of nicotine per kilogram to rats 4 times a day for 3 consecutive days produced an elevation of ethylmorphine and norcodeine metabolism in postmitochondrial supernatant fractions from liver. The chronic administration of nicotine (5.9 $\mathrm{mg} / \mathrm{kg} /$ day) in the drinking water for 7 days produced an elevation in the metabolism of ethylmorphine, norcodeine, and aniline by liver microsomes. This increased enzyme activity was maintained for 5 weeks when nicotine was continued at that dose. However, if the dose was lowered below $4.4 \mathrm{mg} /$ $\mathrm{kg} /$ day, the increased activity was not maintained. The activities of tryptophan pyrrolase and tyrosine transaminase were not altered by chronic drug treatment. An increase in the capacity of liver microsomes to synthesize protein was observed when nicotine treatment was continued for 4 weeks. These data indicate (1) that an elevation of microsomal drug-metabolizing enzymes can be achieved after the acute administration of nicotine, but only when convulsive doses are given several times a day, suggesting that the increased activity after acute drug treatment may be a stress-related event; and (2) that the chronic administration of nicotine can increase the activity of drug-metabolizing enzymes, possibly by inducing enzyme synthesis.
\end{abstract}

In the past few years there has been a vast expansion of knowledge in the area of drug interactions. One aspect of the problem that has received particular attention is modification of the effects of drugs by the concurrent or previous exposure to other drugs and chemical agents which alter drug metabolism (Conney, 1967). In view of the prevalence of the smoking habit it is pertinent to know what effects exposure to tobacco smoke may have on the activity of drug-metabolizing enzymes. It is well known that

\footnotetext{
1 This investigation was supported by a grant from the American Medical Association Education and Research Foundation. A preliminary report of this work has been presented at the FASEB meetings in Atlantic City, New Jersey, April, 1969.

2 Predoctoral trainee supported by National Institute of Mental Health Fellowship MH 37949-02.
} 
3,4-benzpyrene and various other polycyclic hydrocarbons which are found in tobacco smoke enhance the activity of drug-metabolizing enzymes (Conney, 1967). The effect of nicotine itself, or metabolites of nicotine, on the activity of enzymes involved in drug metabolism is less well established. Wenzel and Broadie (1966) reported that the administration of nicotine to mice caused a decrease in the period of ataxia produced by meprobamate and that the metabolism of meprobamate was increased in liver homogenates prepared from mice treated for 2 days with nicotine. Yamamoto et al. (1966) found that pretreatment of rats with large doses of nicotine $(30-40 \mathrm{mg} / \mathrm{kg} \mathrm{ip})$ in corn oil produced an increase in 2-acetylaminofluorene metabolism and benzpyrene hydroxylase activity in the postmitochondrial supernatant from treated animals 24 hours after drug administration. However, the metabolism of 2-acetylaminofluorene declined below control levels if nicotine was given for 2 or 3 days prior to enzyme assay. Beckett and Triggs (1967) have stated that the metabolism of nicotine was greater in smokers than in nonsmokers on the basis that the amount of unchanged nicotine excreted in the urine was less in smokers than in nonsmokers after the administration of nicotine by various routes. Whether this apparent increased metabolism was due to nicotine or other constituents of tobacco smoke was not evident. In addition, Welch et al. (1968) have reported that enzymatic hydroxylation of 3,4benzpyrene was elevated in placental tissue obtained from smokers when compared to tissue from nonsmokers. Moreover, treatment of pregnant rats with benzpyrene increased the activity of the hydroxylase in the placenta. Thus, it seemed that components of tobacco smoke other than nicotine may have produced this increase.

The present study was undertaken to determine what effects the acute and chronic administration of nicotine have on the activity of various enzyme systems and the synthesis of nucleic acids and protein in rat liver.

\section{METHODS}

\section{Acute Studies}

Male Sprague-Dawley rats (Spartan Farms, Lansing, Michigan), weighing 150-200 $\mathrm{g}$, were maintained in a temperature-controlled room with a constant light-dark cycle ( 7 hours of darkness, 17 of light per 24 hours) with access to food and water ad libitum. Animals were injected ip with saline or nicotine (base) and sacrificed by decapitation at the same time each morning (8-9 AM). The livers were immediately removed, placed in Dounce homogenizing tubes on ice, and homogenized.

Tryptophan pyrrolase (EC 1.13.1.12) activity was assayed in whole homogenates by measuring the quantity of kynurenine produced (in the absence of exogenous hematin) according to the method of Feigelson and Greengard (1961). Drug-metabolizing enzymes were assayed in the $12,500 \mathrm{~g}$ supernatant fraction, prepared by homogenization in 4 volumes of a solution containing $0.25 \mathrm{~m}$ sucrose-1 $\mathrm{mm}$ disodium EDTA and centrifugation of the homogenate at $12,500 \mathrm{~g}$ for $20 \mathrm{~min}$ at $0^{\circ}$. The $N$-dealkylation of ethylmorphine and $O$-dealkylation of norcodeine were determined by a modification of the method of Rubin et al. (1964) in a 5-ml reaction mixture which contained: 0.5 mmole of phosphate buffer ( $\mathrm{pH} 7.4$ ), 0.3 mmole of $\mathrm{KCl}, 10.5 \mu$ moles of $\mathrm{MgCl}_{2}$, $38 \mu$ moles of semicarbazide hydrochloride, $6 \mu$ moles of glucose 6 -phosphate, 0.55 
$\mu$ moles of NADP, $4 \mu$ moles of ethylmorphine or norcodeine, and $12-15 \mathrm{mg}$ of $12,500 \mathrm{~g}$ supernatant protein. The samples were incubated for $15 \mathrm{~min}$ at $37^{\circ}$, and the reactions were stopped by the addition of $0.4 \mathrm{ml}$ of $70 \%$ perchloric acid. Metabolism was estimated by the production of formaldehyde, which was determined by a modification of the method of Nash (1953). Nicotine oxidase activity was assayed in a reaction mixture similar to that described above except that the mixture contained $10^{-4} \mathrm{M}$ NADPH, $30-35 \mathrm{mg}$ of $12,500 \mathrm{~g}$ supernatant protein, and $250 \mu \mathrm{g}$ of nicotine as substrate. The mixtures were incubated for $30 \mathrm{~min}$ at $37^{\circ}$, and the disappearance of nicotine was determined by the method of Hug, Tsujimoto, and Ruddon (to be published). Basically, the procedure involved the extraction of nicotine base into $15 \mathrm{ml}$ of hexane from samples $\left(3 \mathrm{ml}\right.$ ) which had been brought to $\mathrm{pH} 11$ with concentrated $\mathrm{NH}_{4} \mathrm{OH}$. A $10-\mathrm{ml}$ aliquot of the hexane phase was added to $5 \mathrm{ml}$ of $0.1 \mathrm{~N} \mathrm{HCl}$. $\Lambda \mathrm{fter}$ shaking and centrifugation, the hexane was aspirated, and the absorbance at $259 \mathrm{~nm}$ of an aliquot of the aqueous phase was determined. Extraction of nicotine from tissue samples by this method was $99 \pm 5 \%$.

Protein determinations were done by the method of Lowry et al. (1951).

Statistical analyses were performed using Student's $t$ test.

\section{Chronic Studies}

Male rats, weighing $60-80 \mathrm{~g}$, were started on the regimen. Nicotine base was dissolved in the drinking water $(40 \mathrm{mg} / \mathrm{liter})$ and placed in amber bottles. Fresh nicotine solution was added to the drinking bottles each day throughout the study. Frequent spectrophotometric analysis of the drinking solutions after 24 hours' storage indicated that nicotine was not destroyed under these conditions. Water consumption was monitored daily, and the average dose throughout the study was calculated on a $\mathrm{mg} / \mathrm{kg} /$ day basis. A control group of animals of the same age, size, and sex was placed in a similar environment and allowed access to untreated drinking water ad libitum. Both groups of animals were maintained on Purina rat chow ad libitum. The nicotinetreated animals gained weight at a rate of $33 \mathrm{~g} /$ week, and the controls gained an average of $47 \mathrm{~g} /$ week over a 5-week study period. Both groups of animals maintained water consumption at relatively the same level ( $\mathrm{ml}$ consumed/g/day) throughout the study.

Animals were sacrificed at weekly intervals after the initiation of treatment. The livers were immediately excised and homogenized in 5 volumes of ice-cold $0.32 \mathrm{M}$ sucrose containing $3 \mathrm{mM} \mathrm{MgCl} 2$. The homogenate was centrifuged at $12,500 \mathrm{~g}$ for 20 min, and the supernatant fraction was then centrifuged at $105,000 \mathrm{~g}$ for 2 hours in a Spinco 40 rotor at $0^{\circ}$ to obtain the microsomal pellet.

Metabolism of ethylmorphine and norcodeine was determined in microsomes by a modification of the method of George and Tephly (1968). Reaction mixtures $(5 \mathrm{ml})$

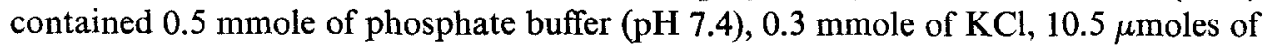
$\mathrm{MgCl}_{2}, 38 \mu$ moles of semicarbazide hydrochloride, $6 \mu$ moles of glucose 6-phosphate, $2.2 \mu$ moles of NADP, $4 \mu$ moles of ethylmorphine or norcodeine, 2 units of glucose-6phosphate dehydrogenase, and 10-12 $\mathrm{mg}$ of microsomal protein. The samples were incubated for $10 \mathrm{~min}$ at $37^{\circ}$, and formaldehyde production was determined as above. Aniline hydroxylation was measured in a 5-ml reaction mixture which contained: 0.3 
mmole of Tris- $\mathrm{HCl}(\mathrm{pH} 7.8), 0.26$ mmole of $\mathrm{KCl}, 10 \mu$ moles of $\mathrm{MgCl}_{2}, 6 \mu$ moles of glucose 6-phosphate, $2.2 \mu$ moles of NADP, $20 \mu$ moles of aniline hydrochloride, 2 units of glucose-6-phosphate dehydrogenase, and 10-12 $\mathrm{mg}$ of microsomal protein. The samples were incubated for $15 \mathrm{~min}$ at $37^{\circ}$, and the production of $p$-aminophenol was determined by the method of Kato and Gillette (1965). Tyrosine transaminase (EC 2.6.1.5) activity was measured in $105,000 \mathrm{~g}$ supernatant by the method of Wurtman and Larin (1968).

Purified nuclei were obtained by centrifugation through $2.4 \mathrm{M}$ sucrose by the method of Pogo et al. (1966). RNA polymerase activity was assayed in nuclei by the method of Pogo et al. (1966) except that incubations were carried out for $4 \mathrm{~min}$ at $37^{\circ}$ (incorporation of ATP- ${ }^{14} \mathrm{C}$ into RNA was linear for $6 \mathrm{~min}$ and was dependent on the presence of nucleoside triphosphates), and the nuclear sediments were filtered on Millipore filters after addition of trichloroacetic acid (TCA) and repeated washing. The filters were then dried overnight; toluene scintillator was added, and the samples were counted in a Packard Tri-Carb liquid scintillation spectrometer.

DNA template activity was determined using a DNA-RNA-protein complex isolated from rat liver by the method of Swingle and Cole (1966). The DNA complex isolated by this method, using $p$-aminosalicylate-phenol extraction, contained $30-60 \%$ RNA, and 1-10\% protein. The properties of this complex suggested that it was not an artifact of preparation and that the presence of this complex in liver is related to the rapid rate of protein and RNA synthesis in this tissue (Swingle and Cole, 1966). The template activity of this complex was assayed using partially purified RNA polymerase (EC 2.7.7.6; Micrococcus lysodeikticus) and DNA polymerase (EC 2.7.7.7; Escherichia coli) as previously described (Ruddon and Johnson, 1968). DNA determinations were performed by the method of Burton (1952).

Protein synthesis was assayed in liver microsomes using a 1-ml incubation mixture which contained (in $\mu$ moles unless otherwise indicated): 35 Tris- $\mathrm{HCl}, \mathrm{pH} \mathrm{7.6;10}$ $\mathrm{MgCl}_{2} ; 25 \mathrm{KCl} ; 6 \beta$-mercaptoethanol, 250 sucrose; 2 ATP, 1 GTP, 10 phosphoenolpyruvate, 0.1 each of 19 unlabeled amino acids, $0.5 \mu \mathrm{Ci}$ phenylalanine- ${ }^{14} \mathrm{C}, 7$ units pyruvate kinase, and $0.5-1.0 \mathrm{mg}$ each of microsomal and $105,000 \mathrm{~g}$ supernatant protein. Polyuridylic acid $(100 \mu \mathrm{g})$ was added to some of the samples. In the absence of poly $\mathrm{U}$, incorporation of labeled phenylalanine was linear for 6-10 min, and incubations were carried out for $5 \mathrm{~min}$ at $37^{\circ}$. With the addition of poly $\mathrm{U}$, incorporation was linear for $20 \mathrm{~min}$, and 10-min incubations were employed. The reactions were stopped with cold $5 \% \mathrm{TCA}$, washed twice with $5 \% \mathrm{TCA}$, heated to $80-90^{\circ}$ for $20 \mathrm{~min}$, and filtered on Millipore filters. The filters were dried overnight and counted as above.

\section{Materials}

Ethylmorphine and norcodeine were gifts from Merck and Co. Thymidine-2-14 C-5'triphosphate $(30.3 \mathrm{mCi} / \mathrm{mmole})$, adenosine- ${ }^{14} \mathrm{C}$ (u.l.) $5^{\prime}$-triphosphate $(440 \mathrm{mCi} /$ mmole), and L-tyrosine-3,5-3 $\mathrm{H}(25 \mathrm{Ci} / \mathrm{mmole})$ were purchased from New England Nuclear Corp. L-Phenylalanine-14 C (u.1.) $(15.3 \mathrm{mCi} / \mathrm{mmole})$ was obtained from Nuclear-Chicago Corporation. RNA polymerase ( $M$. lysodeikticus) was purchased from Miles Laboratories, Inc. DNA polymerase ( $E$ coli) was prepared in our laboratory as previously described (Ruddon and Johnson, 1968). 


\section{RESULTS}

Effects of Acute Administration of Nicotine on Enzyme Activity

Tryptophan pyrrolase (TP) and tyrosine transaminase (TT) are amino acidmetabolizing enzymes found in liver tissue and subject to several types of adaptive and regulatory mechanisms. The activity of these enzymes has been reported to be affected by hormones (Lin and Knox, 1957; Feigelson and Feigelson, 1965; Kenney et al, 1967), level of substrate (Lin and Knox, 1957; Schimke, 1967), feeding schedule (Potter et al., 1966), inherent circadian rhythms (Potter et al., 1966; Wurtman et al., 1968), feedback control by NADPH (TP only) (Cho-Chung and Pitot, 1967), and brain

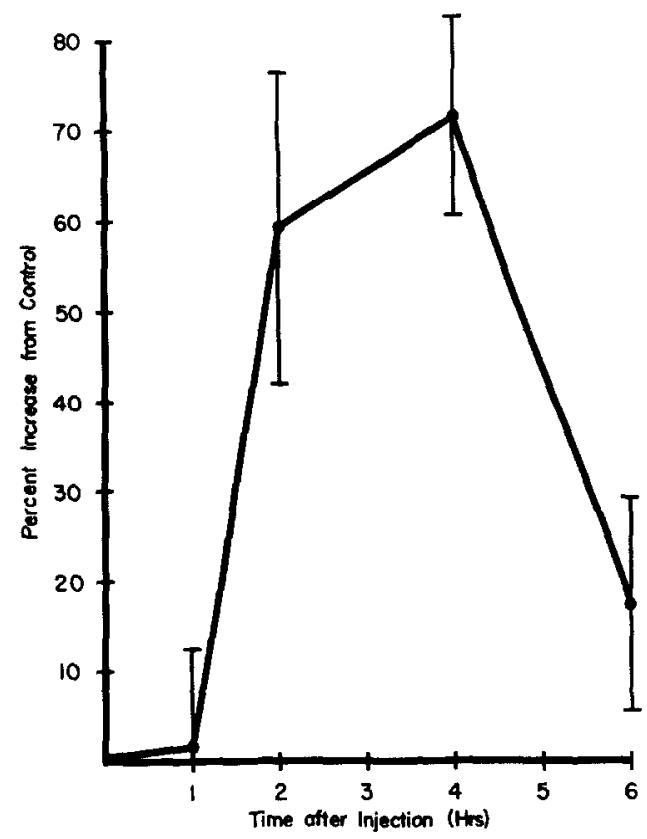

FIG. 1. Effect of nicotine injection on tryptophan pyrrolase (TP) activity in rat liver. Nicotine $(4 \mathrm{mg} / \mathrm{kg}$ ) was injected ip into rats, and the animals were sacrificed at various times after injection. TP was assayed as described in the Methods. Values represent mean \pm SE for 4-6 animals at each point.

norepinephrine levels (TT only) (Black and Axelrod, 1968). Induction by corticosteroids has been shown to involve the synthesis of new RNA (Peterkofsky and Tomkins, 1968), presumably involving a "derepression" mechanism. There is some evidence that regulation of the activities of these two enzymes can also take place at the level of translation of mRNA into protein (Kenney et al., 1967; Tomkins et al., 1965). It was thought that if the administration of nicotine altered processes that affected control mechanisms in liver, monitoring of these two enzymes might serve as a useful tool to detect these alterations. Figure 1 illustrates the levels of TP after the acute administration of $4 \mathrm{mg}$ of nicotine per kilogram. The activity of the enzyme appeared to reach a peak at 4 hours after drug administration. A similar but less marked increase of TP 


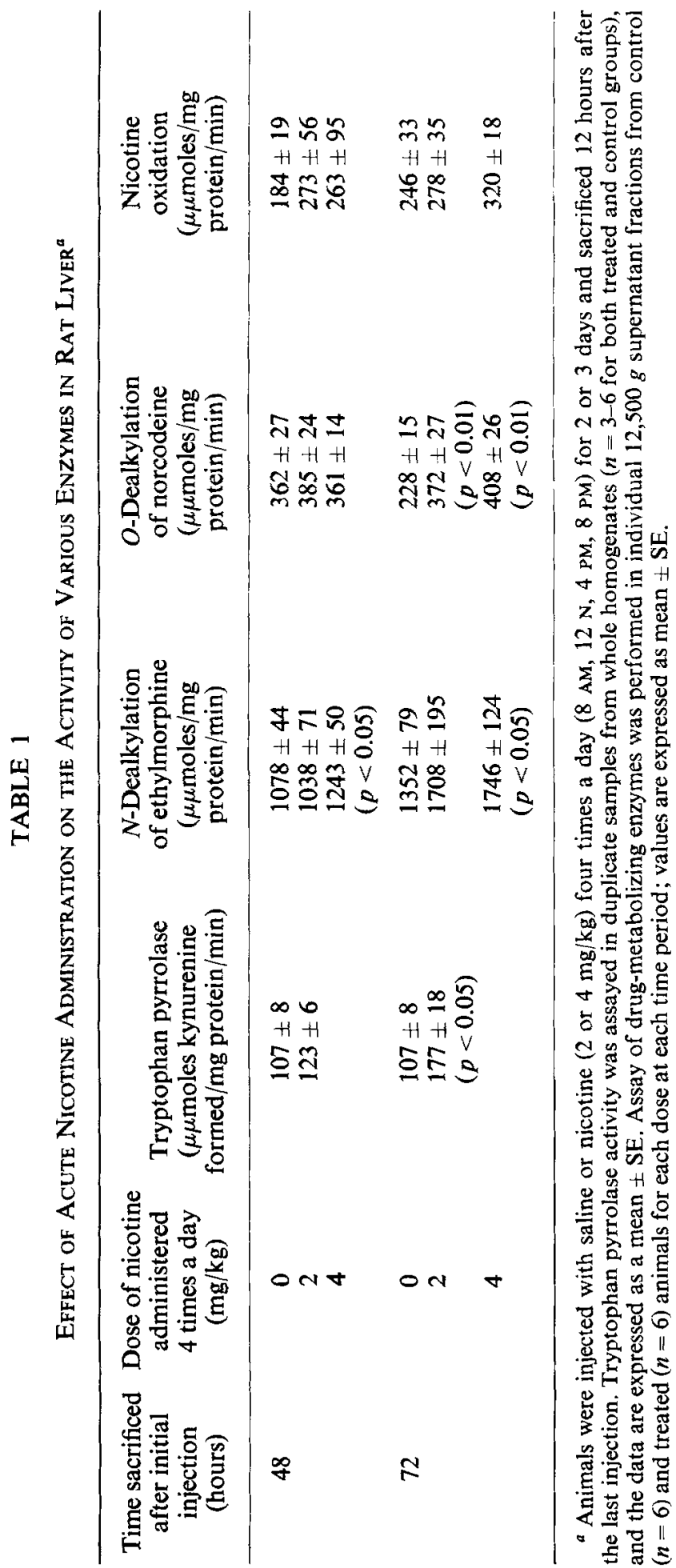


activity was noted after $2 \mathrm{mg} / \mathrm{kg}$ of nicotine. The kinetics of elevation of TP activity are suggestive of adrenocorticosteroid release; the ip administration of cortisone or hydrocortisone produces an increase in liver TP activity which is remarkably similar (Feigelson and Feigelson, 1965). Both 2 and $4 \mathrm{mg} / \mathrm{kg}$ doses of nicotine produced convulsions in the rats, and it is likely that a pronounced effect on the adrenocorticalhypothalamic-pituitary axis also occurred.

The effects of the injection of 2 or $4 \mathrm{mg} / \mathrm{kg}$ of nicotine 4 times a day for up to 3 days on TP and various drug-metabolizing enzymes are shown in Table 1 . TP activity was significantly elevated above control at 72 hours after drug treatment was begun with a daily dose of $8 \mathrm{mg} / \mathrm{kg}$. The metabolism of ethylmorphine (EM) was increased at 48 and 72 hours after the initiation of treatment, but only with the $4 \mathrm{mg} / \mathrm{kg}$ dose. The $O$-dealkylation of norcodeine $(\mathrm{NC})$ was elevated above control at 72 hours by both the

\section{TABLE 2}

Effect of Direct Addition of Nicotine to $12,500 \mathrm{~g}$ Supernatant on the ACtivity of Drug-Metabolizing EnZYMes ${ }^{a}$

\begin{tabular}{ccc}
\hline $\begin{array}{c}\text { Concentration of } \\
\text { nicotine } \\
(\mathrm{M})\end{array}$ & $\begin{array}{c}N \text {-Dealkylation of } \\
\text { ethylmorphine } \\
(\mu \mu \text { moles/mg protein/min })\end{array}$ & $\begin{array}{c}\text { O-Dealkylation of } \\
\text { norcodeine } \\
(\mu \mu \text { moles } / \mathrm{mg} \text { protein } / \mathrm{min})\end{array}$ \\
\hline 0 & 850 & 439 \\
$10^{-3}$ & 455 & 228 \\
$10^{-4}$ & 900 & 333 \\
$10^{-5}$ & 861 & 472 \\
\hline
\end{tabular}

a Activities were assayed in duplicate samples of $12,500 \mathrm{~g}$ supernatant fractions prepared and pooled from the livers of two animals.

2 and $4 \mathrm{mg} / \mathrm{kg}$ doses. Nicotine metabolism was not significantly increased above control at any of the times examined. Thus the microsomal enzymes responsible for metabolism of these drugs appeared to be increased only after convulsive doses of nicotine, and the elevations that were seen may reflect a response to stress brought about by repeated injection of such large doses of drug. It should be noted that when nicotine was administered once a day ip ( 2 or $4 \mathrm{mg} / \mathrm{kg}$ ) or sc in peanut oil (15 or 30 $\mathrm{mg} / \mathrm{kg}$ ) for 3 consecutive days, no elevation of drug-metabolizing enzymes was observed.

The direct addition of nicotine to the $12,500 \mathrm{~g}$ supernatant fraction (Table 2) had little effect on the metabolism of EM or NC except at the highest concentration employed $\left(10^{-3} \mathrm{M}\right)$, at which concentration there was a depressant effect. Assuming uniform distribution of a $4 \mathrm{mg} / \mathrm{kg}$ dose of nicotine, a concentration of $2.5 \times 10^{-5} \mathrm{M}$ could conceivably be achieved in vivo; however, there were no marked effects of nicotine on EM or NC metabolism when nicotine was added to the reaction mixtures in this concentration range. This could be interpreted to mean that the observed augmentation of drug-metabolizing enzyme activity was due to something other than an "activation" of the enzyme system by a direct effect of nicotine. 


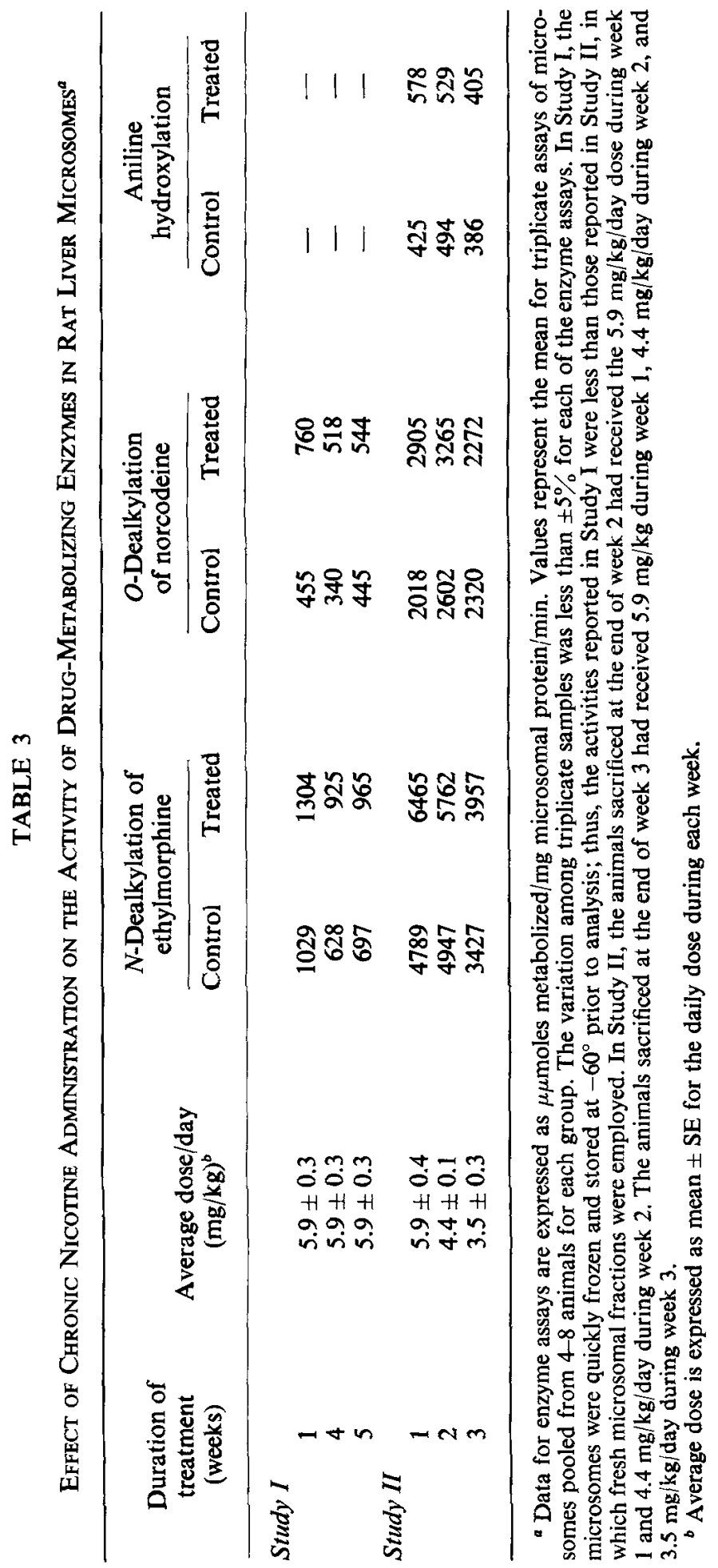


Effects of Chronic Administration of Nicotine on Enzyme Activity, Nucleic Acid Synthesis, and Protein formation

The chronic oral administration of nicotine produced an elevation of both EM and NC metabolism in liver microsomes (Table 3). An average dose of $5.9 \pm 0.3 \mathrm{mg} / \mathrm{kg}$ / animal/day was maintained throughout Study I. The increased activity was apparent

\section{TABLE 4}

Effect of Chronic Nicotine Administration on the Activity of Tryptophan Pyrrolase and Tyrosine Transaminase in Rat Liver ${ }^{a}$

\begin{tabular}{|c|c|c|c|c|}
\hline \multirow{2}{*}{$\begin{array}{l}\text { Duration of } \\
\text { treatment } \\
\text { (weeks) }\end{array}$} & \multicolumn{2}{|c|}{$\begin{array}{l}\text { Tryptophan pyrrolase } \\
\text { ( } \mu \mu \mathrm{moles} \text { kynurenine } \\
\text { formed/mg protein/min) }\end{array}$} & \multicolumn{2}{|c|}{$\begin{array}{c}\text { Tyrosine transaminase } \\
(\mu \mu \text { moles PHPPA } \\
\text { formed } / \mathrm{mg} \text { protein } / \mathrm{min})\end{array}$} \\
\hline & Control & Treated & Control & Treated \\
\hline 2 & $176 \pm 10$ & $176 \pm 8$ & $660 \pm 50$ & $610 \pm 40$ \\
\hline 3 & $224 \pm 12$ & $185 \pm 8$ & $590 \pm 40$ & $650 \pm 20$ \\
\hline
\end{tabular}

${ }^{a}$ Values are expressed as mean $\pm \mathrm{SE}$ for 4-8 animals per group.

${ }^{b} p$-Hydroxyphenylpyruvic acid.

after 1 week of drug administration and was still evident when the animals were treated for 4-5 weeks. A second study was initiated, again starting with a dose of $5.9 \mathrm{mg} / \mathrm{kg} /$ day. After 1 week of treatment there was about a $40 \%$ increase above controls in the metabolism of EM, NC, and aniline by liver microsomes. However, when the dose was lowered to $4.4 \mathrm{mg} / \mathrm{kg}$ /day during the second week of treatment, the elevation of activity of drug-metabolizing enzymes diminished. During the third week the dose was lowered to $3.5 \mathrm{mg} / \mathrm{kg}$, and the elevated activity previously observed in the nicotine-treated rats essentially disappeared. Thus, apparently a daily dose of 4.4 $\mathrm{mg} / \mathrm{kg}$ or greater of nicotine is needed to produce an elevation in the ability of liver microsomes to metabolize drugs.

TABLE 5

Effect of Chronic Nicotine Administration on Nucleic Acid Synthesis ${ }^{\alpha}$

\begin{tabular}{|c|c|c|c|c|c|c|}
\hline \multirow{2}{*}{$\begin{array}{l}\text { Duration of } \\
\text { nicotine } \\
\text { administration } \\
\text { (weeks) }\end{array}$} & \multicolumn{2}{|c|}{$\begin{array}{c}\text { RNA synthesis in } \\
\text { purified nuclei } \\
\left(\mu \mu \text { moles ATP-1 }{ }^{4} \mathrm{C}\right. \\
\text { incorporated/mg DNA) }\end{array}$} & \multicolumn{2}{|c|}{$\begin{array}{c}\text { DNA template } \\
\text { activity in RNA } \\
\text { polymerase system } \\
\text { (m } \mu \text { moles UTP-14C } \\
\text { incorporated/mg DNA) }\end{array}$} & \multicolumn{2}{|c|}{$\begin{array}{c}\text { DNA template } \\
\text { activity in DNA } \\
\text { polymerase system } \\
\text { (m } \mu \text { moles TTP. }{ }^{4} \mathrm{C} \\
\text { incorporated/mg DNA) }\end{array}$} \\
\hline & Control & Treated & Control & Treated & Control & Treated \\
\hline 1 & 122 & 106 & 3.73 & 2.76 & 108 & 112 \\
\hline 2 & 105 & 114 & 1.98 & 1.88 & 153 & 155 \\
\hline 4 & 125 & 131 & - & $\sim$ & - & - \\
\hline 5 & 120 & 121 & 2.10 & 2.43 & 108 & 92 \\
\hline
\end{tabular}

a Values represent the mean for triplicate assays performed with nuclei or DNA samples pooled from nicotine treated (6-8) or control (4-6) animals. 
The data in Table 4 indicate that the chronic administration of nicotine $(5.9 \mathrm{mg} / \mathrm{kg} /$ day) did not significantly alter the activities of tryptophan pyrrolase or tyrosine transaminase, two enzymes that are responsive to a number of environmental and metabolic stimuli.

The ability of purified nuclei and partially purified DNA to synthesize nucleic acids and the capacity of liver microsomes to fabricate proteins were also examined during the chronic administration of nicotine $(5.9 \mathrm{mg} / \mathrm{kg} /$ day). The data in Table 5 indicate that nuclear RNA synthesis was not markedly altered by chronic nicotine administration. The template ability of the DNA-protein complex isolated from livers of control and treated animals also was not significantly differcnt after 5 weeks of drug administration. However, there was an elevation of protein synthesis by liver microsomes 4 weeks after the initiation of treatment (Table 6). At that time, there was a $30-40 \%$

TABLE 6

Effect of Chronic Nicotine Administration on in Vitro Protein Synthesis in Microsomal Fraction from Rat LiVer

\begin{tabular}{|c|c|c|c|c|}
\hline \multirow{3}{*}{$\begin{array}{l}\text { Duration of } \\
\text { nicotine } \\
\text { administration } \\
\text { (weeks) }\end{array}$} & \multicolumn{4}{|c|}{ Count $/$ min phenylalanine- ${ }^{14} \mathrm{C}$ incorporated/mg protein } \\
\hline & \multicolumn{2}{|c|}{ Endogenous messenger } & \multicolumn{2}{|c|}{ +Poly U } \\
\hline & Control & Treated & Control & Treated \\
\hline 1 & 47 & 34 & 157 & 115 \\
\hline 2 & 25 & 18 & 99 & 101 \\
\hline 4 & $99^{a}$ & 130 & 251 & 359 \\
\hline
\end{tabular}

\footnotetext{
" Specific activity of labeled amino acid was increased to achieve higher incorporation of radioactivity.

stimulation of polypeptide formation both by endogenous messenger and in the presence of added poly $U$. The direct addition of nicotine in concentrations of $10^{-5}$ to $10^{-3} \mathrm{M}$ to the in vitro reaction mixtures had no significant effect on nuclear RNA synthesis, DNA template activity, or microsomal protein synthesis.
}

\section{DISCUSSION}

The results of this study indicate that the acute and chronic administration of nicotine to rals can produce elevations of enzymatic activity in liver tissue. The observation that the peak increase in TP activity occurred at 4 hours after the acute ip administration of nicotine suggested that this action of the drug might be related to corticosteroid release. Recently, however, Magus et al. (1968) have reported that the subcutaneous injection of nicotine ( $2 \mathrm{mg} / \mathrm{kg}$ at 0 time and again 2 hours later) produced a slight but statistically significant activation of TP in adrenalectomized rats when measured 4 hours after the initial injection. Thus, part of our observed effects might be due to other direct or indirect effects of nicotine on TP levels in liver. At any rate, it should be emphasized that in our studies, increases in drug-metabolizing enzymes after acute nicotine administration were only observed when convulsive doses were administered 
four times a day. Therefore, the "stress" produced by injection of such large doses of nicotine might have been responsible for the elevations of drug-metabolizing enzyme activity noted after treatment for 48 or 72 hours. There is evidence that stressful environmental manipulations or the injection of corticosteroids can increase the capacity of liver microsomes to metabolize drugs (Furner and Stitzel, 1968; Arrhenius, 1968).

When nicotine was given chronically in a dose of $5.9 \mathrm{mg} / \mathrm{kg} /$ day in the drinking water so that the drug was administered over a 24-hour period in a more even way, no apparent toxicity was noted. It should be pointed out that nicotine is readily absorbed after oral administration (Goodman and Gilman, 1965). This treatment schedule would also be expected to maintain blood and tissue levels of nicotine over a more prolonged period of time than the acute ip injections. The results of these studies indicated that when nicotine is given chronically, an increase in the activity of certain microsomal drug-metabolizing enzyme systems can be produced. The magnitude of these elevations was in the order of $25-50 \%$, and the increased activity could not be maintained when the average daily dose was lowered below $4.4 \mathrm{mg} / \mathrm{kg}$. Thus, nicotine when given chronically in doses of this magnitude is a relatively weak "inducing agent" when compared to phenobarbital or certain polycyclic hydrocarbons (Conney, 1967). As a point of comparison, a human who smokes 1 pack of cigarettes a day absorbs about $1 \mathrm{mg} / \mathrm{kg} /$ day and a 2-pack-a-day smoker absorbs about $2 \mathrm{mg} / \mathrm{kg} /$ day (Larson et al., 1961). Thus, a dose of $5-6 \mathrm{mg} / \mathrm{kg} /$ day in a rat would not seem to be an unreasonable comparison. Furthermore, even though nicotine appears to be a relatively weak "inducer," the combination of nicotine with the polycyclic hydrocarbons found in tobacco smoke may result in a significant elevation of certain microsomal drug-metabolizing enzymes in individuals that are prone to the smoking habit.

The possibility also exists that various metabolites of nicotine may play a role in the alterations of liver enzyme activity noted in these studies. For example, Yamamoto et al. (1966) reported that cotinine, an oxidative metabolite of nicotine, was about as potent as nicotine (when the drugs were given in doses of $40 \mathrm{mg} / \mathrm{kg}$ ) in the ability to increase benzpyrenc hydroxylase activity in rat liver. However, preliminary experiments in our laboratory indicate that no significant alteration of microsomal enzymes occurs when cotinine is administered chronically in the drinking water at doses of $5-6 \mathrm{mg} / \mathrm{kg} /$ day.

It is not clear at this point whether nicotine is acting as an "inducing" agent (i.e., increasing the amount of enzyme present) or as an "activating" agent which stimulates the function of a key component, without stimulating its synthesis or inhibiting its degradation, in the drug metabolism system. The observation that chronic nicotine treatment can increase the capacity of liver microsomes to synthesize protein indicates that nicotine has the potential to act as an inducing agent. In addition, Yamamoto et al. (1966) have reported that the increased activity of microsomal drug-metabolizing enzymes noted in rat liver after acute nicotine treatment $(40 \mathrm{mg} / \mathrm{kg}$ ) was blocked by prior administration of ethionine.

\section{ACKNOWLEDGMENTS}

The authors wish to thank Cynthia Rainey, Linda Galligher, and Greg Smith for their excellent technical assistance. 


\section{REFERENCES}

ARRHENIUS, E. (1968). Effects on hepatic microsomal N- and C-oxygenation of aromatic amines by in vivo corticosteroid or aminofluorene treatment, diet, or stress. Cancer Res. 28, 264-273.

Beckett, A. H., and Triggis, E. J. (1967). Enzyme induction in man caused by smoking. Nature 216, 587.

BlACK, I. B., and AxELRoD, J. (1968). Elevation and depression of hepatic tyrosine transaminase activity by depletion and repletion of norepinephrine. Proc. Natl. Acad. Sci. U.S. 59, 1231-1234.

BURTON, K. (1952). A study of the conditions and mechanism of the diphenylamine reaction for the colorimetric estimation of deoxyribonucleic acid. Biochem. J. 62, 315-323.

Cho-Chung, Y. S., and PITor, N. C. (1967). Feedback control of rat liver tryptophan pyrrolase. I. End product inhibition of tryptophan pyrrolase activity. J. Biol. Chem. 242, 1192 1198.

Conney, A. H. (1967). Pharmacological implications of microsomal enzyme induction. Pharmacol. Rev. 19, 317-366.

Feigelson, M., and Feigelson, P. F. (1965). Metabolic effects of glucocorticoids as related to enzyme induction. Advan. Enzyme Regulation 3, 11-27.

Feigelson, P. F., and GreENGARD, O. (1961). A microsomal iron-porphyrin activator of rat liver tryptophan pyrrolase. J. Biol. Chem. 236, 153-157.

Furner, R. L., and Stitzel, R. E. (1968). Stress-induced alterations in microsomal drug metabolism in the adrenalectomized rat. Biochem. Pharmacol. 17, 121-127.

George, W. J., and TePhly, T. R. (1968). Studies on hepatic microsomal N- and O-dealkylation of morphine analogues. Mol. Pharmacol. 4, 502-509.

Goodman, L. S., and Gilman, A. (1965). The Pharmacological Basis of Therapeutics, 3rd ed., p. 582. Macmillan, New York.

KATO, R., and GilLETTE, J. R. (1965). Effect of starvation on NADPH-dependent enzymes in liver microsomes of male and female rats. J. Pharmacol. Exptl. Therap. 150, 279-284.

Kenney, F. T., Holten, D., and Albritton, W. L. (1967). Hormonal regulation of liver enzyme synthesis. Natl. Cancer Inst. Monograph. 27, 315-323.

Larson, P. S., HaAG, H. B., and Silvette, H. (1961). Tobacco: Experimental and Clinical Studies. Williams \& Wilkins, Baltimore, Maryland.

LIN, E. C. C., and KNox, W. E. (1957). Adaptation of the rat liver tyrosine- $\alpha$-ketoglutarate transaminasc. Biochim. Biophys. Acta 26, 85-88.

Lowry, O. H., Rosebrough, N. J., FARR, A. L., and RANDALL, R. J. (1951). Protein measurement with the Folin phenol reagent. J. Biol. Chem. 193, 265-275.

Magus, R. D., Rickert, D. E., and Fouts, J. R. (1968). Activation of hydrocortisoneinduced tryptophan pyrrolase of rat liver by SKF 525-A. Biochem. Pharmacol. 17, 20712080.

NASH, T. (1953). The colorimetric estimation of formaldehyde by means of the Hantzsch reaction. Biochem. J. 55, 416-421.

Peterkofsky, B., and Tomkins, G. M. (1968). Evidence for the steroid-induced accumulation of tyrosine-aminotransferase messenger RNA in the absence of protein synthesis. Proc. Natl. Acad. Sci. U.S. 60, 222-228.

Pogo, A. O., Allfrey, V. G., and Mirsky, A. E. (1966). Evidence for increased DNA template activity in regenerating liver nuclei. Proc. Natl. Acad. Sci. U.S. 56, 550-557.

PotTer, V. R., Gebert, R. A., and Pitot, H. C. (1966). Enzyme levels in rats adapted to 36-hour fasting. Advan. Enzyme Regulation 4, 247-265.

Rubin, A., Tephly, T. R., and Mannering, G. J. (1964). Kinetics of drug metabolism by hepatic microsomes. Biochem. Pharmacol. 13, 1007-1016.

RudDon, R. W., and Johnson, J. M. (1968), The effects of nitrogen mustard on DNA template activity in purified DNA and RNA polymerase systems. Mol. Pharmacol. 4, 258-273.

Schimke, R. T. (1967). Protein turnover and the regulation of enzyme levels in rat liver. Natl. Cancer Inst. Monograph 27, 301-314. 
Swingle, K. F., and Cole, L. J. (1966). A DNA-RNA-protein complex isolated from rat liver. J. Mol. Biol. 15, 573-586.

Tomkins, G. M., Garren, L. D., Howell, R. R., and Peterkofsky, B. (1965). The regulation of enzyme synthesis by steroid hormones: The role of translation. J. Cellular Comp. Physiol. 66, suppl. 1, 137-152.

Welch, R. M., Harrison, Y. E., Conney, A. H., Poppers, P. J., and Finster, M. (1968). Cigarette smoking; stimulatory effect on metabolism of 3,4-benzpyrene by enzymes in human placenta. Science 160, 541-542.

Wenzel, D. G., and BroAdie, L. L. (1966). Stimulatory effect of nicotine on the metabolism of meprobamate. Toxicol. Appl. Pharmacol. 8, 455-459.

WURTMAN, R. J., and LARIN, F. (1968). A sensitive and specific isotopic assay for the estimation of tyrosine transaminase. Biochem. Pharmacol. 17, 817-818.

Wurtman, R. J., Shommaker, W. J., and LarIN, F. (1968). Mechanism of the daily rhythm in hepatic tyrosine transaminase activity: Role of dietary tryptophan. Proc. Natl. Acad. Sci. U.S. 59, 800-807.

Yamamoto, I., NAGai, K., Kimura, H., and Iwatsubo, K. (1966). Nicotine and some carcinogens in special reference to the hepatic drug-metabolizing enzymes. Japan. J. Pharmacol. 16, 183-190. 